\title{
The Effectiveness of Innovative Processes in Enterprises Taking Advantage of the Technology Audit
}

\author{
Zofia Gródek Szostak ${ }^{1 *}$, Luis Ochoa Siguencia ${ }^{2}$ and Danuta Kajrunajtys ${ }^{3}$ \\ ${ }^{1}$ Department of Economics and Enterprise Organization, Cracow University of Economics, Poland \\ ${ }^{2}$ Department of Sport and Tourism Management, Academy of Physical Education in Katowice, Poland \\ ${ }^{3}$ Department of International Management, Cracow University of Economics, Poland
}

Submission: November 14, 2018; Published: December 17, 2018

*Corresponding author: Zofia Gródek Szostak, PhD, ul. Rakowicka 27, 31-510 Krakow, Poland

Abstract

Background \& Purpose: The economic purposes of innovation in enterprises result from their growth strategy. Usually, they comprise replacing the products that are at the end of their life cycle and are withdrawn from the market, broadening the product offer, creating environmentally friendly products, maintaining or increasing the market share, winning new foreign and domestic markets, or increasing the production's flexibility. Technology audit is one of the special forms of the internal audit in an enterprise. It is not required by law, and usually it does not play a controlling role.

Methodology: Authors have identified 50 enterprises based in the region of Malopolska that have subjected their potential to analysis through a technology audit carried out by a third party (a Business Environment Institution). The research was carried out both on-line, as well as during site visits and personal meetings with the owner or the management. Basic organizational and financial information was prepared by persons delegated by the management/the owner of the enterprise. The target selection was used to select the research sample, determined by the purpose of the research, i.e. to provide information on the effectiveness of the innovation processes in enterprises using the technology audit. Previously, pilot studies were carried out, which allowed to prepare a background for the research described in this article.

Results: $70 \%$ of respondents, who are planning to precede their next innovation with a diagnosis of the innovative potential in the form of a technology audit also plan to establish cooperation with an R\&D center soon. It might be presumed that this is the consequence of an increased awareness of applying the methodological approach to the next innovative process.

Keywords: Innovations; Technology Audit; Enterprise

\section{Introduction}

In today's enterprises, the meaning of innovation results, among others, from increasing social needs, which can be met mainly thanks to science and its achievements. According to Pomykalski [1], the ability to create and absorb innovation is the greatest challenge of the 21st century. The author defines innovation as a process that involves all activities related to creating an idea, then an invention, and ultimately, to implementing the new (or improved) product, process, or service [1]. In approaching the issue of innovation, it is stressed that the ability to innovate is the prerequisite for the competitive advantage, i.e. the company's commercial success. The unique character of innovation as a creative process is stressed repeatedly, however the issue of costs of innovation, or the difficulty in balancing the proportion between innovation and the entity's day-to-day functioning.

Innovation is defined in several ways by economics, psychology and other sciences. In psychology, this idea is discussed, especially in terms of individual ingenuity and talent, and the reasons behind them. In the psychological aspect, innovativeness is associated with creativity, or the ability to think divergently, taking up risk and learning. In sociology, innovativeness is presented as a function of the social system, or as a result of the process of social defining of reality [2]. According to Grzywacz [3], innovation should be treated as an economic category, and not technical, i.e. it must bring tangible benefits to the producer and/or users through more efficient use of resources and increased value of the needs that it meets.

Technological progress, or any other that does not contribute to increased productivity or usefulness, is not innovation. Nowadays, innovativeness is considered a particularly important quality of entrepreneurship [3]. Machaczka [4] points out that innovation should bring economic effect; the function of entrepreneurship is to transform an idea or project into a specific product or service, which satisfies a specific need and is able to generate profit. As a 


\section{Annals of Social Sciences \& Management studies}

result, the process allows the entrepreneur to recreate, or even increase the future production cycles.

Upon analyzing literature, one could conclude that there is no uniform approach to interpreting the idea of effectiveness, both in various academic disciplines and among practitioners [5]. Analyzed in the macro scale, effectiveness is traced back to the problem of social welfare, the main premise of which is effective allocation of limited resources [6]. On the other hand, experts in management theory believe that effectiveness is the measuring instrument of efficacy in management [7]. There is also the opinion that an efficiency analysis is not possible without assessing its effectiveness. In other words, information on effectiveness has a higher informative value than the information on effectiveness [8]

Specialists emphasize that efficiency is a multidimensional concept, indicating e.g. the following dimensions of efficiency [9].

a) economic, containing criteria to present the relationship between the effects and investments

b) financial, measured based on past financial indicators

c) market, measuring the degree of satisfying customers' needs

d) system, illustrating the condition of the enterprise as a system or its subsystems in relation to long-term goals, such as survival, development or the ability to change, and the socalled characteristics of potential systems, such as innovation

e) dynamic (developmental), regarding the ability to create new products and to acquire new skills

f) operational, referring to the productivity of production processes

g) political, including the relations of the enterprise with the environment

h) cultural, emphasizing the company's ability to consolidate and cultivate the norms and values that allow to preserve the cultural identity of the society and contribute to the development of culture

i) social, expressing the interests of employees and company owners in terms of social needs and roles

j) ecological, emphasizing the impact of the company on the environment and relations with the environment.

According to Mariusz Bielski [10], however, there is no single best criterion for assessing effectiveness. The selection is subjective and is influenced by the value, preferences and interests of the entity making the assessment. Therefore, a single, synthesized criterion of organizational efficiency can't be derived and formulating a uniform and universal multicriteria evaluation system is not possible. Such a system must be constructed individually, considering the genetic function of the organization, the set of current goals and their hierarchy set by the management, and finally, the organization's objective from which the assessment is made.

\section{Materials and Methods}

The economic goals of innovation result from development strategies of enterprises. Typically, they consist of: replacing products that are withdrawn from the market due to the end of their life cycle, expanding the range of products, creating environmentally friendly products, maintaining market share or increasing it, winning new foreign and domestic markets, and increasing production flexibility. An important goal is to reduce production and product design costs, as well as the amount of deficiencies, to reduce the cycles of preparation and launching of production, to increase the quality of products, to improve working conditions and to reduce the level of environmental risk [11]. However, understanding the nature of innovation poses many difficulties.

The category of a technologically innovative company has been identified in source literature in early 1990s. Jasiński [12] was the first to describe it in Polish literature. In his opinion, "an innovative company is one that:

a) conducts a wide range of R\&D works (or purchases new products or technologies),

b) allocates relatively large funds for this activity,

c) sys

d) tematically implements new technological and scientific solutions,

e) consistently introduces innovations to the market [12].

Technology entrepreneurs, i.e. entrepreneurs who apply new technology in practice, use technology as a driving force, a factor that increases competitiveness. Technological entrepreneurs are changing the world by introducing new technologies to the market. This forces companies to constantly improve and modernize their products, technological processes regarding places and forms of sale, and methods of contacts with clients. This requires constant restructuring. Therefore, the design processes, as well as the research on technological processes can't rely solely on changes made based on the diagnosis of current solutions but must consider the premises resulting from forecasts and marketing [13].

Technology audit is one of the special forms of internal audit in an enterprise. It is not required by law and usually does not have a control function - as in the case of an internal audit defined by the Public Finance Act. It is a method of assessing an enterprise in terms of [14]: its technological potential, applied procedures, and needs. Performing a technology audit must allow determining the company's needs in individual areas related to innovations, including [13]:

a) positioning of the company's products/markets,

b) technical areas such as: automation, IT, packaging, etc.

c) company functions that require innovative solutions: efficiency, quality, flexibility, energy consumption, etc. 
d) channels of technology transfer to the enterprise, both used and potential

e) potential for acquiring new technological solutions.

\section{The Implementation of Such Plans Requires the Analy- sis of the Entire Enterprise.}

Technology audit is usually carried out by external consultants working closely with the management and employees of the audited company. One of the results of the audit should be a report in which an action plan is formulated, leading to strengthening the technological position and acquiring the necessary technologies and knowledge.

The effects of the entire analysis of the company's situation are included in the final report, which should be as concise and precise as possible. The document should contain an overview of the situation, along with directions for the company regarding future activities. The report should include the following $[15,16]$.

a) An analysis of the company's market situation. The report includes the main conclusions along with their justification and characteristics. It is a mistake to post detailed analyzes that, on the one hand, could be incomprehensible for the readers, usually the owners of SMEs, and, on the other hand, obvious for those who perfectly know the operational conditions of the company they manage.

b) Most often, the SWOT analysis is used as the main tool for the overall analysis of the company. The resulting conclusions should be presented in such a way as to be a kind of guide on issues relevant to the readers of the report.

c) Technological goals. They should be formulated based on the analysis of relations between technology and individual areas of the company's activity.

d) Directions of activities are an important element of the report. They form the basis for the discussion between the company's management and the consultants on the interpretation of the results. The directions constitute a proposal for the management as to solutions related to the improvement of the company's situation.

\section{Results}

The authors identified 50 enterprises based in the Małopolska region, which had their potential analyzed with a technology audit performed by an external entity (a Business Environment Institution). The research was carried out both on-line, as well as during site visits and personal meetings with the owner or the management. Basic organizational and financial information was prepared by persons delegated by the management/owner of the enterprise. The target selection was used to select the research sample, determined by the purpose of the research, i.e. to provide information on the effectiveness of the innovation processes in enterprises using the technology audit.

Previously, pilot studies were carried out, which allowed to prepare a background for the research described in this article $[17,18]$. Therefore, the survey was addressed to enterprises from the SME sector that have carried out the completed technological, product and process implementations preceded by an audit. The research drew attention to a change in the situation in the analyzed enterprises, which resulted from the technology transfer process. The period preceding the implementation of the project (n-1) was compared with the period after the implementation of the innovation process $(n+1)$.

Each time, the initiating stage of the cooperation was an indepth diagnosis of the organization's needs and the construction of a logical matrix defining the purpose of the planned undertaking. The conducted technology audit was the answer to the following questions:

a) What is the innovative potential of the company?

b) Are your resources enough?

c) What is the organization's achievements in the area of know-how and intellectual property protection?

Recommendations from the conducted technology audit included potential sources of support for technology transfer processes from public funds. By the decision of the owner or the management board, after the report was approved, the second stage of supporting the innovation processes in the organization was initiated, i.e.

a) obtaining public support for the implementation of the R\&D project

b) strengthening the cooperation with BEI and R \& D developed at the technology audit stage, handling the process of national technology transfer

c) managing the transfer of technology in the organization.

Table 1: The effects of the conducted technology audit in the area of organization's innovation.

\begin{tabular}{|c|c|c|c|c|}
\hline $\begin{array}{l}\text { Type of Inno- } \\
\text { vation }\end{array}$ & Product & Process & Organizational & Marketing \\
\hline $\begin{array}{l}\text { The main fac- } \\
\text { tors initiating } \\
\text { innovations }\end{array}$ & $\begin{array}{c}\text { Technology audit } \\
\text { Customer requirements }\end{array}$ & $\begin{array}{l}\text { Customer requirements } \\
\text { Technology audit } \\
\text { Limited possibilities of research } \\
\text { Limitations in the implementa- } \\
\text { tion of research in domestic and } \\
\text { international consortia }\end{array}$ & $\begin{array}{l}\text { Limited human resources } \\
\text { Requirements of individual } \\
\text { grant programs }\end{array}$ & $\begin{array}{c}\text { Technology audit } \\
\text { Verification of industry-specific } \\
\text { national and international data- } \\
\text { bases of cooperation partners }\end{array}$ \\
\hline
\end{tabular}




\begin{tabular}{|c|c|c|c|c|}
\hline $\begin{array}{l}\text { Means of } \\
\text { verification } \\
\text { before imple- } \\
\text { menting the } \\
\text { innovation }\end{array}$ & $\begin{array}{l}\text { The number of unfinished } \\
\text { procedures } \\
\text { The number of services not } \\
\text { introduced to the offer } \\
\text { The number of non-imple- } \\
\text { mented technologies }\end{array}$ & $\begin{array}{l}\text { The number of projects that } \\
\text { have been refused participation } \\
\text { The number of lost research } \\
\text { opportunities in national and } \\
\text { international projects }\end{array}$ & $\begin{array}{l}\text { Assessment based on ver- } \\
\text { ification carried out by the } \\
\text { owner/management }\end{array}$ & $\begin{array}{l}\text { The number of unused distribu- } \\
\text { tion channels } \\
\text { Lack of participation in promo- } \\
\text { tional industry events (e.g. trade } \\
\text { fairs, partner meetings) }\end{array}$ \\
\hline $\begin{array}{l}\text { Means of } \\
\text { verification } \\
\text { after imple- } \\
\text { menting the } \\
\text { innovation }\end{array}$ & $\begin{array}{l}\text { Increase in the number of } \\
\text { accepted orders } \\
\text { Financial criteria (increase } \\
\text { in revenues from rendered } \\
\text { services) } \\
\text { The number of new services } \\
\text { introduced to the offer } \\
\text { The number of implemented } \\
\text { innovative technologies } \\
\text { (confirmed by a written } \\
\text { opinion on innovation) }\end{array}$ & $\begin{array}{l}\text { Increase in the number of proj- } \\
\text { ects implemented in national } \\
\text { partnerships } \\
\text { The number of international } \\
\text { contacts established in the im- } \\
\text { plementation of joint ventures } \\
\text { An increase in the number of } \\
\text { national and international con- } \\
\text { ferences promoting research } \\
\text { achievements }\end{array}$ & $\begin{array}{l}\text { Increase in the number of } \\
\text { full-time contracts net } \\
\text { Fulfilling formal and sub- } \\
\text { stantive access criteria of } \\
\text { applying for support under } \\
\text { structural research and } \\
\text { investment programs } \\
\text { An extensive network of } \\
\text { cooperation between BEI } \\
\text { and R\&D }\end{array}$ & $\begin{array}{l}\text { Diversification of distribution } \\
\text { channels regarding information } \\
\text { about the offer } \\
\text { Placing the technological offer in } \\
\text { national and international offer } \\
\text { databases } \\
\text { Participation in national and in- } \\
\text { ternational events promoting the } \\
\text { service offer } \\
\text { Participation in national and inter- } \\
\text { national competitions promoting } \\
\text { innovative enterprises. }\end{array}$ \\
\hline
\end{tabular}

Among the surveyed enterprises, 10 implemented national/ international technology transfer when implementing innovations in their organization, based on audit recommendations (Table 1). It is also worth noting that $70 \%$ of respondents, who are planning to precede their next innovation with a diagnosis of the innovative potential in the form of a technology audit also plan to establish cooperation with an $\mathrm{R} \& \mathrm{D}$ center soon. It might be presumed that this is the consequence of an increased awareness of applying the methodological approach to the next innovative process.

\section{Conclusion}

Enterprises that take advantage of the technology audit increase the market efficiency of their business processes by better matching innovation activities to strategic goals. Being aware of their innovative potential assessed by an independent organization, enterprises can choose transfer activities adequate to their capabilities and own resources. The technology audit, i.e. assessing the organization's achievements in the area of knowhow and intellectual property protection, matches the designed activities with the employees' experience, which means that they can quickly use innovations and incorporate them into the company's offers. The effectiveness of innovative processes of companies taking advantage of the technology audit was confirmed by quantitative research and in-depth interview. Business managers strongly emphasized the impact of the technology audit on the economic decisions made.

\section{References}

1. Pomykalski A (2001) Innowacje Politechnika Łódzka Łódź.

2. Borkowski T, Marcinkowski A (2004) 0 wielowymiarowym rozumieniu innowacji, proinnowacyjnych organizacjach i proinnowacyjnym myśleniu, Zmiana warunkiem sukcesu, AE Wrocław.

3. Grzywacz W (1995) Metodyka polityki gospodarczej, Polskie Towarzystwo Ekonomiczne Szczecin.

4. Machaczka J (2001) Podstawy zarządzania AE Kraków Kraków.
5. Skrzypek E (2012) Efektywność-konceptualizacja i uwarunkowania Prace Naukowe Uniwersytetu Ekonomicznego we Wrocławiu 262: 313-314.

6. Stiglitz JE (2004) Ekonomia sektora publicznego PWN Warszawa.

7. Pohl H (1998) Zarządzanie logistyką. Funkcje i instrumenty, Biblioteka Logistyka, Instytut Logistyki i Magazynowania Poznań.

8. Frey K, Widmer T (2009) The role of efficiency analysis in legislative reforms in Switzerland, [in:] $5^{\text {th }}$ ECPR General Conference, Potsdam, Germany.

9. Martyniak Z (2000) Efektywność organizacji Ekonomika i Organizacja Przedsiębiorstw.

10. Bielski M (2002) Podstawy teorii organizacji i zarządzania CH Beck Warszawa.

11. Dworczyk M, Szlasa R (2001) Zarządzanie innowacjami Oficyna Wydawnicza Politechniki Warszawskiej.

12. Jasiński AH (1992) Przedsiębiorstwo innowacyjne na rynku KiW Warszawa.

13. Gródek-Szostak Z (2011) Audyt technologiczny w strategii konkurencyjnej innowacyjnego przedsiębiorstwa Zeszyty Naukowe Wyższej Szkoły Ekonomii i Informatyki w Krakowie nr 7: 149-157.

14. Głodek P, Gołębiowski M (2003) Transfer technologii w małych i średnich przedsiębiorstwach - Vademecum innowacyjnego przedsiębiorcy Uniwersytet w Białymstoku - Wschodni Ośrodek Transferu Technologii.

15. Kalinowski TB (2007) Rola systemów zarządzania jakością we wprowadzaniu innowacji produktowych i organizacyjnych rozprawa doktorska maszynopis powielony Łódź.

16. Kajrunajtys D (2016) Obieg informacji na potrzeby konkurowania organizacji w turbulentnym otoczeniu, Zeszyty Naukowe Wyższej Szkoły Ekonomii i Informatyki w Krakowie 12: 124-140.

17. Gródek-Szostak Z, Kajrunajtys D (2010) Audyt technologiczny jako narzędzie budowy przewagi innowacyjnej przedsiębiorstwa - studium przypadku Labortest sp. z o.o. [in:] S Miklaszewski \& B Mikuła (Eds.), Zarządzanie Rozwojem Przedsiębiorstw i Instytucji. Krakow: Biuro Projektu Nauka i Gospodarka.

18. Gródek-Szostak Z (2010) Audyt technologiczny - rola i znaczenie w zarządzaniu innowacyjnym przedsiębiorstwem, Euroekspert" no. 1, Białystok. 

(C) This work is licensed under Creative DOI: 10.19080/ASM.2018.02.555590

\section{Your next submission with Juniper Publishers} will reach you the below assets

- Quality Editorial service

- Swift Peer Review

- Reprints availability

- E-prints Service

- Manuscript Podcast for convenient understanding

- Global attainment for your research

- Manuscript accessibility in different formats

( Pdf, E-pub, Full Text, Audio)

- Unceasing customer service

Track the below URL for one-step submission https://juniperpublishers.com/online-submission.php 